\title{
The Strategy of Geography Teachers in Implementing Standards Process of Permendikbud Number 22 the Year 2016 on Geography Learning in SMA Negeri Solok Regency
}

\author{
* Dewilna Helmi ${ }^{1)}$ and Febriandi ${ }^{2)}$
}

1) Student Geography of Science, Padang State University, INDONESIA

2) Department of Geography, Universitas Negeri Padang, INDONESIA

Email: dewilnahelmi@gmail.com

*Corresponding Author, Received: January 15, 2018, Revised: March 02. 2018, Accepted: May 20, 2018

This is an open acces article distributed under the Creative Commons 4.0 Attribution License, wich permits unregtricted use, Distribution, and reproduction in any medium provided the original work is properly cited @2017 by author and Universitas Negeri Padang

\begin{abstract}
The purpose of this research to know the implementation of standard process that consists of analyzing the lesson plan that prepared by the teacher, analyzing the implementation of learning process, seeing the constraints in implementing the standard process, formulating the teacher strategy in implementing process standard and decreasing the priority of policy direction in implementing process standard in SMA Negeri Solok Regency. The type of research used a mixed method which combines qualitative and quantitative research. Data were collected through, observation, interview, and documentation. Data analysis methods consist of reduction, presentation and verification, SWOT analysis and Interpretive Structural Modeling. The results of the research indicate that: 1) the implementation of standards process seen in the teacher's learning plan has designed syllabus and lesson plan but not fully in accordance with the steps and components of RPP preparation.2) In the implementation of classroom management learning process still not fully in accordance with standards process. Judging from the methods, models, media mastery of the material has not been effective and efficient according to the 2013 curriculum this was due to the lack of understanding of teachers towards the curriculum of 2013, from the assessment of learning outcomes in all three aspects of the assessment conducted only the assessment of knowledge, to attitudes assessment and skills not implemented maximally. 3) The obstacle faced is the unavailability of time in the preparation of the implementation plan of learning because the burden of teaching is high enough, difficulties in the implementation of learning are influenced by low student learning interest and in the assessment of learning still constrained by time. 4) There were nine strategies derived from field research. 5) Priority policy directives that arise to improve the implementation of process standards in geography learning were: Increased interest of teachers in training activities held in MGMP forums so as to improve teacher competence, Curriculum Training 2013 to improve understanding of the reforms conducted in ministerial regulations, academic supervision by school principals and teachers to improve teachers' ability to manage the classroom, and to develop media and interesting learning resources to foster student interest in learning.
\end{abstract}

Keywords: Geography Teacher Strategy, Implementation of Standards Process

\section{Introduction}

Education is a very important thing for humans in life. This is in accordance with the opinion of Jambak (2017), education is one of the decisive factors for the progress of a nation. The quality of education affects the quality of human resources to build and improve the nation's overall development. One of the formal institutions provided by the government to implement education is the school. The goal is that education can 
be organized to create intelligent and useful people for the life of the nation. This is in accordance with "the goal of National Education No. 20 of 2003 on National Education System states: Education is a conscious and planned effort to create an atmosphere of learning and learning process that learners actively develop their potential to have spiritual strength, self-control, personality of intelligence, noble character, and skills needed, society, nation, and state.

To ensure the achievement of these educational objectives, the government has mandated the drafting of eight national education standards as stipulated in the Government Regulation of the Republic of Indonesia no. 19 of 2005 and has been amended by Government Regulation No. 32 of 2013 on National Education Standards containing the National Education Standards, one of the standards that must be developed is the standard process as it relates to the implementation of learning on educational units to achieve quality education process. Indonesia is one of the countries that have the low quality of education in the international world this can be seen from several international studies on the ability of Indonesian students in the international arena. According to Mulyasa (2013), the results of a study of Indonesian students' abilities from the 2007 Trend International Math and Science, conducted by the Global Institute, show that only 5 percent of Indonesian students are able to answer the reasoning problem in high categorized, whereas Korean learners can reach 71 percent. In contrast, 78 percent of Indonesian students can work on low-caliber memorabilia, while only 10 percent of Korean learners and the Program for International Student Assessment (PISA) disclose the results of their study in 2009 put Indonesia at the lower level of 55 out of 65 PISA participating countries. From the two study results, it can be concluded that the quality of education in Indonesia is still low compared to other countries.

Related to the above issues, the Government needs to pay attention to the quality of Indonesian education. In this case, the government made changes and curriculum development, which began with the arrangement of four elements of standards educational, including graduation competency standards (SKL), content standards, process standards, and assessment standards. With the change and curriculum development, it is expected that the quality of Indonesian education can be better equal to other countries. The curriculum is one tool that is very important in seeing the success or absence of education, without appropriate curriculum and precisely difficult to achieve a quality education. For that reason, the government always makes improvements to the curriculum starting in 1947 to the current 2013 curriculum.

The success or failure of the implemented curriculum in 2013 is influenced by how the school implements with the maximum implementation of the Process Standards. There are several factors that support the successful implementation of standard processes within the school, such as teacher readiness, a readiness of students, facilities and infrastructure supporting learning and learning processes in the classroom. From several factors above the teacher is a big factor in its influence in implementing the 2013 curriculum. Even teachers are said as the spearhead that is very decisive in achieving the goals of national education. This is in line with Mukarrammah (2015). The curriculum in its technical development is always associated with teacher involvement (educator or teacher) as one of the determinants of the success of the curriculum because the teacher is the determinant object of achieving the competence of learners as part of the curriculum results. In the context of formal education the teacher is the first component in direct contact with the learners in the process of education through the learning process, both the planning stage, the implementation and, the assessment in accordance with the standard process, not least the geography teacher.

Through the renewal of the curriculum in Indonesia using the 2013 curriculum, West Sumatra Province is one of the provinces that must implement it. This resulted in several regencies in West Sumatra province using the 2013 curriculum as curriculum in academic year 2013/2014. Solok regency is no exception that all public schools in Solok regency have applied it from the beginning so that in implementing the learning must be in accordance with educational standards, one of the standards that must be done is the standard process. The process standard in Primary and Secondary Education is regulated in Permendikbud Number 22 of 2016, the learning activities must be in accordance with the standard of a process. Process standards include the instructional planning, instructional execution, assessment of learning processes and monitoring of learning processes. Therefore Geography teachers should implement the learning process in accordance with Permendikbud which has been established by the government. Based on research that researchers find the problems that related to process standards include: the discovery of teachers who have not made RPP as a reference in learning, not attention to the components and steps of making learning planning in accordance 
with process standards, in the implementation of learning is still found teachers who only use lecture method things this is consistent with the results of Nawita research (2017) Geographic learning activities are often done by one-way method, where the teacher becomes the only source of knowledge and position of students become passive listeners who can only accept the lessons given. Because with such methods, teachers assume that time allocation can be efficient, then still the discovery of teachers who do not use the learning media, still the discovery of the implementation of the assessment that is limited to the implementation of knowledge assessment because of constrained time so that no third component of attitude assessment attitudes, assessment of knowledge, and skills assessment. By looking at the various problems that the authors pointed out above, the researchers are interested to examine more deeply the strategy of teachers to implement the standard process Permendikbud Number 22 of 2016 in geography learning in SMA Solok Regency.

\section{Method}

The type of research used a mixed method which combines qualitative and quantitative research. According to Creswell (2014) mix-methods is a research approach that combines or associates qualitative and quantitative forms. Data were collected through, observation, interview, and documentation. Data analysis methods consist of reduction, presentation and verification, SWOT analysis and Interpretive Structural Modeling. The location of the research was conducted in SMA Negeri 1 Bukit Sundi, SMA Negeri 1 Gunung Talang and SMA Negeri 1 Lembang Jaya in Solok Regency.

\section{Results and Discussion}

The related research to the Process Standards that researchers do include learning planning, implementation of the learning process, in line with Sarpiati (2013) and Carli (2013) three important indicators known in the process standard is the preparation of learning planning, implementation of the learning process and assessment of student learning outcomes. According to Rusman (2017), learning is an accumulation of the concept of teaching and the concept of learning. The emphasis lies in the combination of the two, namely to the growth of student activity. The concept can be viewed as a system, so that in this learning system there are components of students or learners, objectives, materials to achieve goals, facilities, facilities and procedures, and media that must be developed. In the implementation of learning process required learning planning. The planning that has been done by teachers in SMA Negeri in Solok regency was to make a lesson plan to develop based on syllabus, this is in accordance with Permendikbud Number 22 the Year 2016 on Learning on Basic Education and Secondary Education, lesson plan was a learning plan developed in detail in the syllabus, textbooks, and teacher manuals. In line with that Rusman (2012) states "Learning planning is a preparation by teachers in the learning process to achieve effective and efficient learning objectives. In research of lesson plan made by teacher of Geography subjects of SMA Negeri of Solok Regency not yet fully make it complete component and there is still preparation of lesson plan which not yet according to the steps that determined in accordance with existing provision but for step preparation of lesson plan teacher have not notice difference students overall because the characteristics of students, in general, were taken only. Implementation of lessons was an implementation of lesson plan in which there were 3 core activities which include preliminary activities of core activities and closing activities, in line with Amri (2013) implementation of learning is the implementation of the lesson plan which includes the activities of the predecessor, core activities and closing activities. In research on the Implementation of Learning Process of Geography subject teachers in SMA Negeri in Solok regency that has been implemented to the 2013 curriculum. This can be seen in the preliminary activities, core activities and closing activities and components contained in the learning process. But not all activities were maximally in accordance with the standard process. In the implementation of preliminary activities have not been implemented maximally in accordance with process standards. It is seen the physical class was not prepared, linking the material now with the previous also has not done it. So, in the classroom, the seats look messy and the class was dirty because the garbage was littered on the floor and in the drawers of learners. Judging from the explanation of the purpose and the benefits were not submitted because the 
assumption was the same as explaining the scope of the material. Whereas in the preliminary activities already stated in Permendikbud Number 22 of 2016 on Standard Process.

Similarly, core activities have not been implemented in accordance with the Standards Process in the 2013 curriculum set by the government. Implementation of core activities can be seen from the mastery of learning materials, application of educational strategies that educate, the application of scientific approach, the use of learning models, utilization, learning resources, learning media, the involvement of learners in learning and the use of correct and appropriate language in learning. Based on the results of the analysis of the authors that the subject of Geography teacher in SMA Negeri Solok Regency, carrying out core activities has not been in accordance with the overall process standards set by the government. Judging from the mastery of the material has not been fully able to link the material with real life and the development of science and technology and then the suitability of the material with the purpose of learning has also not been done. Learning strategies that educate also have not been implemented so that in the learning of the students were often the commotion that shows not being good because teachers who lack the control of the class. Lessons learned were not in accordance with the allocated of $3 \times 45$ minutes (three hours lessons) for class $X$ and $4 \times 45$ minutes (four lessons) for class XI. It caused by slow learners in conducting discussions and lack of time management that has been planned according to the allocated time.

Then based on the analysis of research authors through observation and interviews have not all scientific steps implemented that was for step observing to ask what, why, and how nothing was done because of teachers Geography subjects in SMA N Solok regency who became informant research. The researcher assumes that approach scientifically it can only be done depending on the teaching materials when every learning should develop a scientific approach. This was because the teacher still does not understand the guidelines for the implementation of the curriculum in the form of Permendikbud 2013 Number 22 of 2016 on Learning in Primary and Secondary Education. The utilization of learning resources there were still teachers only make the handbook students and worksheet and the Internet as a source of learning and media use limited to the use of projectors who were still scrambling when in the delivery of material not only through the delivery of the mouth but with the media to be one of support for creating interactive, inspirational, fun, challenging, and motivating children to learn. The last component was the tool/media tool. Means and learning media serves as a tool but will have a very important role. Using the media can increase the motivation and understanding of learners in learning, as Edgar Dale describes in the cone of experience. The cone of experience presented by Edgar Gale in Sanjaya (2013) illustrates that using the media (visual) or direct experience (demonstration) will make it easier for students to receive messages conveyed by teachers rather than relying on verbal language.

For the involvement of learners in the learning of teachers have begun to grow the liveliness of learners in raising questions and opinions but to grow a positive attitude has not been implemented maximally. In closing activities based on the results of research the researcher of teachers Geography subjects in SMA N 1 Solok regency showed not covered activities in accordance with the standard learning process. Based on the analysis of field findings through observation and interviews in the can that teachers still not facilitate and guide learners to summarize the subject matter, as well as reflect on the process and the subject matter was not presented. This was due to the time spent learning because the teacher was too long on the core activities. Another cause was the lack of understanding of the teachers on the Implementation of Process Standards, particularly in this closing activity. The next standard components o process was an assessment, assessment is one of the competencies that must be mastered by the teacher. According to Arifin (2012), Assessment is a process or a systematic and continuous activity to collect information about the process and learning outcomes of learners in order to make decisions based on certain considerations. For the assessment of attitudes, knowledge, and skills were not implemented holistically well. In the attitude, the assessment was done in the form of observation, self-assessment, peers, and journal/teacher notes, but only observation but not always done, and self-assessment has not been implemented because there was no time. For attitude assessment in the form of observation was not adjusted between the technique and instrument with indicators of achievement of competence but only use the format provided by the school, the same also the assessment of knowledge and skills. Whereas in carrying out the assessment should be adjusted with indicators of achievement of competence of each learning and must be adjusted also with the authentic assessment that should have been designed in lesson plan which has been made by the teacher and developed in the learning that was implemented. 
The obstacle faced was the unavailability of time in the preparation of the implementation plan of learning because the burden of teaching was high enough, the difficulties in the implementation of learning were influenced by low student learning interest and in the assessment of learning is still constrained by time. As well as the burden of teaching was too high and the teacher's workload too much. To reduce the constraints faced by teachers it was necessary to improve the professional competence of teachers, this was in line with Sari (2017) in improving the professional competence of teachers need to hold ongoing supervision conducted by supervisor, Principal, provide training and continuous development related to the implementation of learning. From some components of the Standard Process above it takes a strategy in implementing the Standard Process, Majid (2013), the strategy was a pattern that planned and applied deliberately to conduct activities or actions. To determine the strategy of Geography Teachers in Implementing the Standards of Permendikbud Number 22 of 2016 On Geography Learning in State Senior High School of Solok Regency was formulated with SWOT analysis that same as the research conducted by Simponi (2016) in determining the strategy used SWOT analysis. SWOT analysis was a form of analysis within the organization that can systematically assist in the organization that can systematically assist in the preparation of a mature plan to achieve goals, both short-term goals and long-term goals. SWOT analysis compares the external factors of opportunity and threats with internal strength factors and Weakness. The following was a SWOT analysis diagram (Rangkuty, 2016). To perform SWOT analysis, it was necessary first to identify internal factors and external factors in the strategy of teachers in implementing process standards that are conducted using discussions and in-depth interviews with Stakeholders. In doing identification of internal factor hence conducted observation on some strengths and weaknesses that will be faced by the perpetrator of strategy, while to do identification of external factor hence need to be observed opportunity and threat faced in determining teacher strategy in implementing Permendikbud Process Standard No. 22 The year 2016 On Geography Learning in SMA Negeri Solok Regency. From the results of field observations and interviews formulated strengths and weaknesses (internal factors), opportunities and threats (external factors). The following is the alternative of teacher strategy in implementing Permendikbud Standard Process Number 22.

Geography Teacher Policy Strategy Direction In Implementing Standards Permendikbud Process Number 22 of 2016 On Geography Learning in SMA Negeri Solok Regency. The alternative policy of geography teacher strategy in implementing Standard Process in SMA Negeri Solok regency. Based on the purpose of this research, there were several alternative policies obtained from two aspects that are considered in the standard process, namely learning planning and implementation of learning. Details of some alternative geography teacher strategies in implementing process standards can be described as follows: The strategy formulated into alternative criteria for geographic strategy policy directives to implement the standard process of Permendikbud Number 22 of 2016 on geography study at SMA Negeri Solok regency. There were nine alternatives obtained, namely: 1) Development of strategies and ability of teachers in mastering, preparing and implementing lesson plans 2) Development of varied models and learning methods 3) Increased interest of teachers in training activities held in the MGMP forum. 4) Improvement of facilities and infrastructure supporting the learning process. 5) Training of learner teachers to improve the professional competence of teachers. 6) Curriculum Training 2013 to improve understanding of the reforms carried out in ministerial regulations.7) Improvement of academic supervision activities by the Principal, curriculum and teacher representatives in improving the ability to manage the class. 8) Improve teacher strategy in building cooperation with learners. ) Developing interesting media and learning resources to foster student interest in learning. From some alternatives above will be selected alternative priority using Interpretative Structural Modeling (ISM). According Iswandi (2017) ISM is one of the computer-based methodologies that assist in identifying the relationship between ideas and fixed structure on complex issues. ISM can be used to develop several types of structures, including influence structures (eg support or neglect, priority structures (eg: 'more important than', or 'preferably learned beforehand') and idea categories (eg: 'belong to the same category as ') Then the first step in Interpretative Structural Modeling (ISM) by constructing Structural Self Interaction Matrix (SSIM) using symbols V, A, X and O.

The key elements of data processing above were $\mathrm{T} 2$ and $\mathrm{T} 7$ because $\mathrm{T} 2$ and $\mathrm{T} 7$ have bigger booster than other elements. When viewed from the dependence of these two elements was a key element because it has a larger when compared with other elements. Subsequently, a classification diagram of the sub-element of the teacher policy policy direction process standard. From the above diagram can be known key factors that can be applied that was in quadrant 4 as follows: 1). Increased interest of teachers in training activities held in 
MGMP forums so as to improve teacher competence. 2). Curriculum Training 2013 to improve understanding of the reforms carried out in ministerial regulations. 3). Increasing academic supervision activities by principals and teachers to improve teachers' ability to manage the class. 4). Developing interesting media and learning resources to foster student interest in learning.

\section{Conclusion}

Based on the results of research that the researcher do through observation, interviews, and study documentation and discussion above, then the authors' conclusions on the implementation of standard processes in learning Geography in SMA Solok regency were as follows: (1) Implementation of process standards seen in teacher learning planning already designed syllabus and RPP but not yet fully in accordance with the steps and components of RPP preparation. (2) In the implementation of the classroom management learning process was still not fully compatible with the process standards, implementing the five steps of a truly scientific approach has not been fully implemented. Judging from the methods, models, media mastery of the material has not been effective and efficient according to the 2013 curriculum. Seen from the closing activities there were still teachers who do not summarize the material, reflect on learning and do not conduct feedback activities on learning. This was due to the lack of understanding of teachers towards the curriculum 2013. From the assessment of learning outcomes of the three aspects assessment undertaken only the assessment of knowledge to assess attitudes and skills have not been implemented to the maximum. (3) Constraints faced was the unavailability of time in the preparation of the implementation plan of learning because the burden of teaching was high enough, difficulties in the implementation of learning were influenced by low student learning interest and in the assessment of learning is still constrained. (4) There are nine strategies derived from field research. (5) Priority policy directives emerging for improvement in implementing process standards in geography learning are: Increased teacher interest in training activities held in MGMP forums so as to improve teacher competence, Curriculum Training 2013 to improve understanding of reforms undertaken in ministerial regulations, Upgrading academic supervision activities by school principals and teachers to improve teachers' ability to manage the classroom, and to develop media and interesting learning resources to foster student interest in learning.

\section{References}

Amri, Sofian. (2013). Development and Learning Model in Curriculum 2013. Jakarta: PT Achievement Pustakaraya

Arifin, Zainal. (2012). Evaluation of Learning. Bandung: PT Remaja Rosdakarya Offset.

Carli Wiseza, Fitria. (2013). Quality of Teaching Management of Geography Teachers in Senior High School of Kerinci Regency. Thesis Master of Geography Education FIS UNP. Padang

Creswell,JW., (2014). Research Design : Qualitative, Quantitative and Mixed Methods Approaches:Fourth edition. Sage publication, Inc.

Iswandi, U. (2017). Approach System. Depok: PT RajaGrafindo Persada.

Jambak, Arnapis. (2017). Implementation of Environmental Character Values in Geography Learning at SMA Negeri 1 Kinali. Sumatra Journal of Disaster, Geography ang Geography Education. Vol 1, No. 2, (pp, 369-378), December, 2017.

2016. Permendikbud No. 22 of 2016 on process standards. Ministry of Education and culture

Mukarrammah, Ummi et al. (2015). Standard Analysis of Learning Process of Biology Class X in SMA Negeri 1 Majalengka Lesson Year 2014 / 2015.Institut Islam Islam Negeru (IAIN) Sheikh Nurjati Cirebon. Scientiae Educatia Vol. 5 No. 1 Year 2015.

Majid, Abdul. (2013). Implementation of Curriculum 2013 Theoretical and Practical Studies. Bandung: Interes 
Mulyasa. E. (2013). Communication and Implementation Curriculum 2013. Bandung: Rosdakarya.

Nawita, Yusri. (2017). Active Learning Model in Geography Learning at Indonesian Senior High School (SMA

Kuantan Tengah). Sumatra Journal of Disaster, Geography ang Geography Education. Vol 1, No 2, (pp, 341 346), December, 2017.

Sari, Novita Desy. (2017). Analysis of Teacher Profession Direction Geography Competency in Material Mastering Adaptation and Natural Disaster Mitigation at Lubuak Linggau Urban High School.Sumatra Journal of Disaster, Geography ang Geography Education. Vol 1, No 2, (pp, 298306), December, 2017

Rangkuty, Freddy. (2016). SWOT Analysis Techniques Dissecting Business Cases Orientation Concepts Strategic Planning for Facing the 21st Century. Jakarta: Gramdeia Pustaka Utama.

Rusman. (2012). Learning Models. Jakarta: Raja Grafindo Persada

Rusman. (2017). Learning \& Learning: Education Process-Oriented Standard. Jakarta :Kencana

Sanjaya, Wina. (2013). Planning and Design of Learning Systems. Jakarta: Kencana

Sarpiati. (2013). Implementation of Process Standards In Science Group Subjects (Physics, Biology, Chemistry) at SMA Negeri 1 Tapung Kecamatan Tapung Kampar District. Thesis Master of Education Program Post Graduate UNP.Padang.

Simponi, Maijem. (2016). Evaluation of the Implementation of Curriculum 2013 and Education Unit Level Curriculum (KTSP) on Geography Learning at SMAN Kota Padang. Thesis Master of Geography Education Faculty of Social Sciences, Universitas Negeri Padang. Padang.

Law of the Republic of Indonesia No.20 of 2003 on National Education System. 